University for Business and Technology in Kosovo

UBT Knowledge Center

UBT International Conference

2013 UBT International Conference

Nov 1st, 2:00 PM - 2:15 PM

\title{
E- Banking In Financial Service in Albania
}

Aurela Ramaj

University “Ismail Qemali” Vlore, aurelabifsha@yahoo.ca

Vjollca Hysi

University of Tirana, vhysi@hotmail.com

Follow this and additional works at: https://knowledgecenter.ubt-uni.net/conference

Part of the Business Commons

\section{Recommended Citation}

Ramaj, Aurela and Hysi, Vjollca, "E- Banking In Financial Service in Albania" (2013). UBT International Conference. 43.

https://knowledgecenter.ubt-uni.net/conference/2013/all-events/43

This Event is brought to you for free and open access by the Publication and Journals at UBT Knowledge Center. It has been accepted for inclusion in UBT International Conference by an authorized administrator of UBT Knowledge Center. For more information, please contact knowledge.center@ubt-uni.net. 


\title{
E- Banking In Financial Service in Albania
}

\author{
Aurela Ramaj ${ }^{1}$, Vjollca Hysi ${ }^{2}$ \\ ${ }^{1}$ Department of Busines, Faculty of Economy \\ ${ }^{1}$ University of Vlora "Ismail Qemali", Albania \\ ${ }^{2}$ Head of Marketing Department \\ ${ }^{2}$ Faculty of Economy University of Tirana, Albania \\ aurelabifsha@yahoo.ca',vhysi@hotmail.com²
}

\begin{abstract}
The business environment today is characterized by strong competitive pressures; therefore most companies focus their efforts in maintaining a satisfied customer base. There is a full coherence between management and marketing theorists on the importance of service quality as a key to business success.Companies which produce high quality service also have higher economic returns than their competitors, who are not so oriented services. This is particularly true in financial services where deregulation has created an environment with multiple choices for bank costumers, in meeting their financial needs. In response to this, many financial institutions are focusing their strategies to increase customer satisfaction and loyalty through quality consumer services.Achieving consumer satisfaction via internet banking has found widespread support in the theoretical literature. This makes it imperative to empirical analys is results which will help improve work and management.In this context the main problem of this study will remain the question. How satis fied are customers with quality banking services and does improvement of these services leads to increased customer satisfaction. The study is applied taking into analysis two banks. Raiffeisen Bank (RZB) and National Commercial Bank (BKT).Data Are analyzed using descriptive statistics These data are presented in tables and graphs. Questionnaire include demographic data and consumer questions which aim to attract their opinion about the five key dimensions 1 . Reliability, 2. Accountability, 3. Readiness to provide timely service, 4. Return of banking services from tangible to intangible in consumer banking, 5. Sensitivity. Ass essment of consumer expectations banking is done with scale from "much worse than we expected" "worse than expected", "as expected" in "much better than expected."
\end{abstract}

Keywor ds: e- banking, financial service, consumer service, information.

\section{What is E-banking?}

All banks are present on the internet with a website of their own, which gives general information about the bank and the services it provides. However, internet banking goes a step further, since it allows customers to enter the Internet to their accounts on-line 24 hours a day, 7 days a week, directly from their homes or offices and perform banking operations want. In other words, internet banking can define a range of services, offered through electronic channels of distribution and communication, of traditional and new products and banking services. However, it should be noted that internet banking , at least at the current stage, don't tends to replace the traditional channels of distribution of banking products. He stands with a set of channels, ranging from traditional ones ( like counters subsidiaries ) to the automatic ( like ATMs, Pos ), in the context of fulfilling and strengthening customer report bank, to realize the strategy called multi-channel. 
Table.1 Services provided via the electronic.

\begin{tabular}{|c|c|c|c|c|}
\hline Information & Balance control & $\begin{array}{l}\text { Transfers of } \\
\text { funds }\end{array}$ & Credit & Others \\
\hline Financial product & Account status & Transfers & Credit limit & $\begin{array}{l}\text { Financial } \\
\text { counseling }\end{array}$ \\
\hline Bursa & $\begin{array}{l}\text { Status credit } \\
\text { cards/debits }\end{array}$ & $\begin{array}{l}\text { Repayment of } \\
\text { the loan }\end{array}$ & Application & $\begin{array}{l}\text { Reporting of } \\
\text { incident }\end{array}$ \\
\hline \multirow[t]{2}{*}{ Exchange Rate } & $\begin{array}{l}\text { State personal } \\
\text { checks }\end{array}$ & Direct debiting & $\begin{array}{l}\text { The loan } \\
\text { approval }\end{array}$ & $\begin{array}{l}\text { Management of } \\
\text { personal finance }\end{array}$ \\
\hline & & $\begin{array}{l}\text { Payment with } \\
\text { credit cards }\end{array}$ & Transfer & $\begin{array}{l}\text { Other financial } \\
\text { products }\end{array}$ \\
\hline
\end{tabular}

\subsection{The advantages and benefits of Internet Banking}

Internet banking fulfills many functions in the relationship between the bank and its customers . Besides the presentation and recognition of the banking institution, and its initiatives, this service also offers other benefits such as:

- Convenience: unlike bank counters, bank websites never closed, they are open 24 hours a day, 7 days a week. It is not necessary to lose time waiting in queues, because banks are now just a click away.

- Wherever occurrence: if you are away from your city or even abroad, you can connect directly with the bank and your account and take care of personal finances.

- Quickly of transactions: often, online accounts realize and confirm banking transactions quickly than the ATM slot machines.

- Efficiency: You can access and manage all your accounts, including deposits, pension funds, securities, etc.., And all this from a single web page.

- Effectiveness: a large part of the banks offer on their web sites, sophisticated instruments, alarms or management programs to help you manage all your assets more efficiently.

\subsection{Internet Banking In Albania}

Most of the products offered by commercial banks in Albania, are part of the traditional services deposits, account transfers . Deposits have been the most popular product by the public, but in recent years, efforts to minimize cash transactions ( channeling employees 'salaries through banks ) led to a rapid development for other products ( loans may be mentioned here, overdrafts, cards etc. ). A part of users, initially seen with disbelief these products and tried to stay away from them, but gradually, with increasing amount of information about the advantages of these products, their use is becoming routine . In this process, banks have a key role in educating the public about new products. To serve this purpose, have tightened regulatory requirements for transparency of banking operations with the public ( publication of working conditions clearly and easily accessible to enable their comparison between banks). After familiarization with the above products, is enabled internet banking in Albania.

The above facts speak for internet banking in its infancy in Albania. Although the Albanian market there are banks that have the support of powerful groups of foreign bank, this service is not yet developed. The main reason is cost ratio - benefit. If there is not a significant number of clients who will use this service, the high costs as sociated with its provision, mentioned above, would lead to losses for banks. On the other hand, if you do not provide a certain service is difficult to determine the nu mber of its potential users.

\subsection{E-Banking quality services}

Intensive development of the Internet has also changed the way companies and customers interact. Based on SERVQUAL method used for traditional distribution channels Zeithaml (200.2002) propos ed a measurement instrument with seven service quality dimensions for measuring e-service cilësiën. This 
was followed by a study of the same author SERVQUAL technique compared to the ES-qualconcluding that some traditional dimensions of SERVQUAL module also can be used for in-service quality. But other dimensions associated with this technology are added to this technique.

E-S QUAL initially consisted on 11 dimensions which was further reduced to 7, by Parasuraman. Basic dimensions are: efficiency, system availability, fulfillment of the obligation and Privacy. Additional dimensions are accountability, compensation and contact.

Recent studies show a combination of traditional techniques and dimensions SERQUAL online communications.

Li \& Suomi (2009) proposed eight dimensions of quality electronic services, which are

Web design, reliability, responsiveness, assurance, fulfillment of obligations, personalization, information and empathy.

Following these studies dimensions of electronic service quality can be explored in the context of online services or e-banking.

\section{Methodology and Research Results}

\subsection{Search methods can be statistical or case study.}

This study is based on a combination of qualitative and quantitative methods. Through quantitative methods will be drawn the results from perspective of banking customer. The questionnaire will be used. In questionnaires to the customer goal will be to note the level of demand for banking services, what are the factors that influence the choice of one or the other bank and what consumers expect from Albanians bank. While further qualitative methods are used in order to interpret the quantitative results and to note marketing concept from the perspective of banking structures. In view of this goal will be interviews with local managers and marketing directors at the central level. Both methods help in the accurate measurement of dimensions. This will be a formal study because it goes beyond exploration of facts using well-structured procedures which aim to provide answers to some questions.

\section{Control variables}

The study is non-experimental because we have no control over the variables. The paper may be a statistical analysis or a case study. In our case it is about a case study because it will not raise the hypothesis analysis but will focus specifically on consumers of one or two banks. (RZB \& BKT) The research will be cross-sectional because it refers analysis to a single period of time and not recidivist in different periods.

\subsection{The procedure of data collection}

Determination of sample and population. The population consists of a number of 200 clients whom it is addressed questionnaire.

\section{Source of data}

Are used primary and secondary data. As instruments of data collection will be used questionnaire with clients of banks, as well as structured interviews or semi-structured interviews with bankexecutives. The questionnaire will be built on five dimensions which are pre-tested as dimensions of service quality.

\section{Summary of statistical model}

Data were analyzed using descriptive statistics such as frequency, mean, standard deviation, etc. error allowed. These data are presented in tables and graphs. Questionnaire include demographic data and 
consumer questions which aim to attract their opinion about the five key dimensions that make up the three main dimensions of services:

1. Technical

2. Functional

3. Image

Basic dimensions of services, some of which is required banking customer opinion:

1. Reliability

2. Accountability

3. Readiness to provide timely service

4. Return of banking services from intangible to tangible for banking customer.

5. Sensitivity

Assessment of banking customer expectations will be with scale from "much worse than we expected" "worse than we expected", "as expected", "better than we expected" in "much better than we expected.

\section{Conceptual Perspective of Study}

Based on findings that literature provides is also built the analysis of this study. Used models and concepts presented in the figure below. The Construction of this scheme is based on two main pillars of this study: Consumer satisfaction and quality of services (mainly focused on internet banking). This is done in order to see how evolving consumer satisfaction with improved and the quality of internet banking. Consumer satisfaction is conceived based on a number of banking services and among them The Internet service during the last 12 months, taken from a population of 200 banking customers. Quality of service is also conceived as a process of consumer evolution while the latter increased use of banking services and manly internet banking and this evolution is based on consumer perceptions for banking services and expectations realized by this service. Consumer satisfaction measurement is made using the stairs "much worse than I thought" to "much better than I thought."

For measuring consumer satisfaction are using three categories which are:

a. Levels of Performance-used scale as poor poor, good, very good.

b. Levels of disconfirmation-are scales as worse than what I thought or better than what I expected

c. Levels of satisfaction are those that use a scale from very dissatisfied to very satisfied

\section{Empirical Results and Data Analysis}

This part of the chapter consists of the data and their analysis. The empirical data presented in the following order:

- The data of the interviewees

- Report satisfaction / dissatisfaction of respondents with quality banking services offered by RZB and BKT

- Listing of priority service dimensions 
- The overall level of satis faction for the quality of service to Internet Banking RZB compared with BKT.

Part of the interpretation of the data will analyze the results and findings from research trying to answer the questions raised at the beginning of the study.

Percentages of Responses

Of the 100 questionnaires sent to each bank (BKT \& RZB), 77 questionnaires were returned for RZB and 62 for BKT

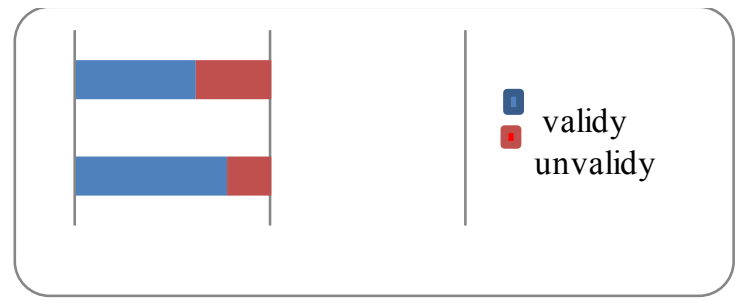

Fig.1 Percentages of responses

\begin{tabular}{lll}
\hline Questionnaires & RZB & BKT \\
\hline Valid & 77 & 62 \\
Invalid & 23 & 38 \\
\hline
\end{tabular}

Source: Primary data processed by the author

Demographic data of respondents
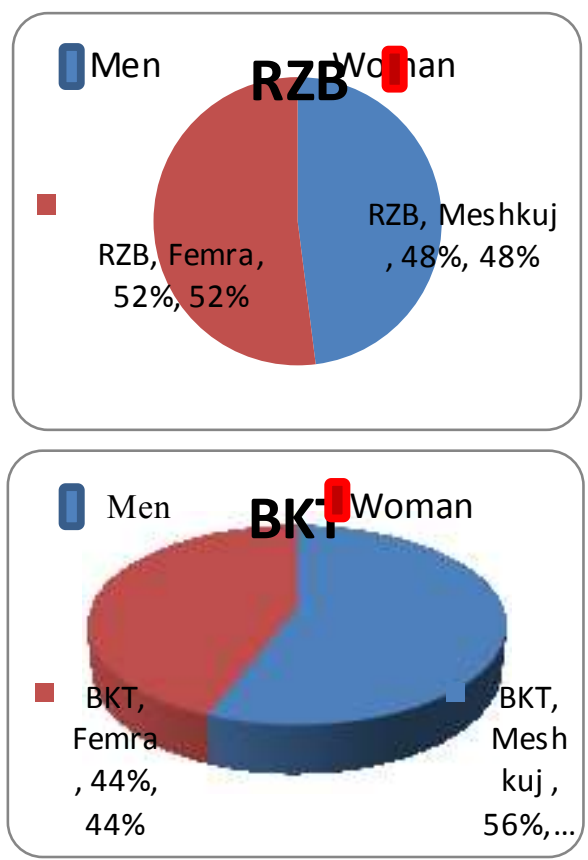

Fig.2 Information on gender

For RZB $48.9 \%$ of respondents were male and $59.1 \%$ were female. For NCB, $56.5 \%$ of respondents were male and $43.5 \%$ were female. 

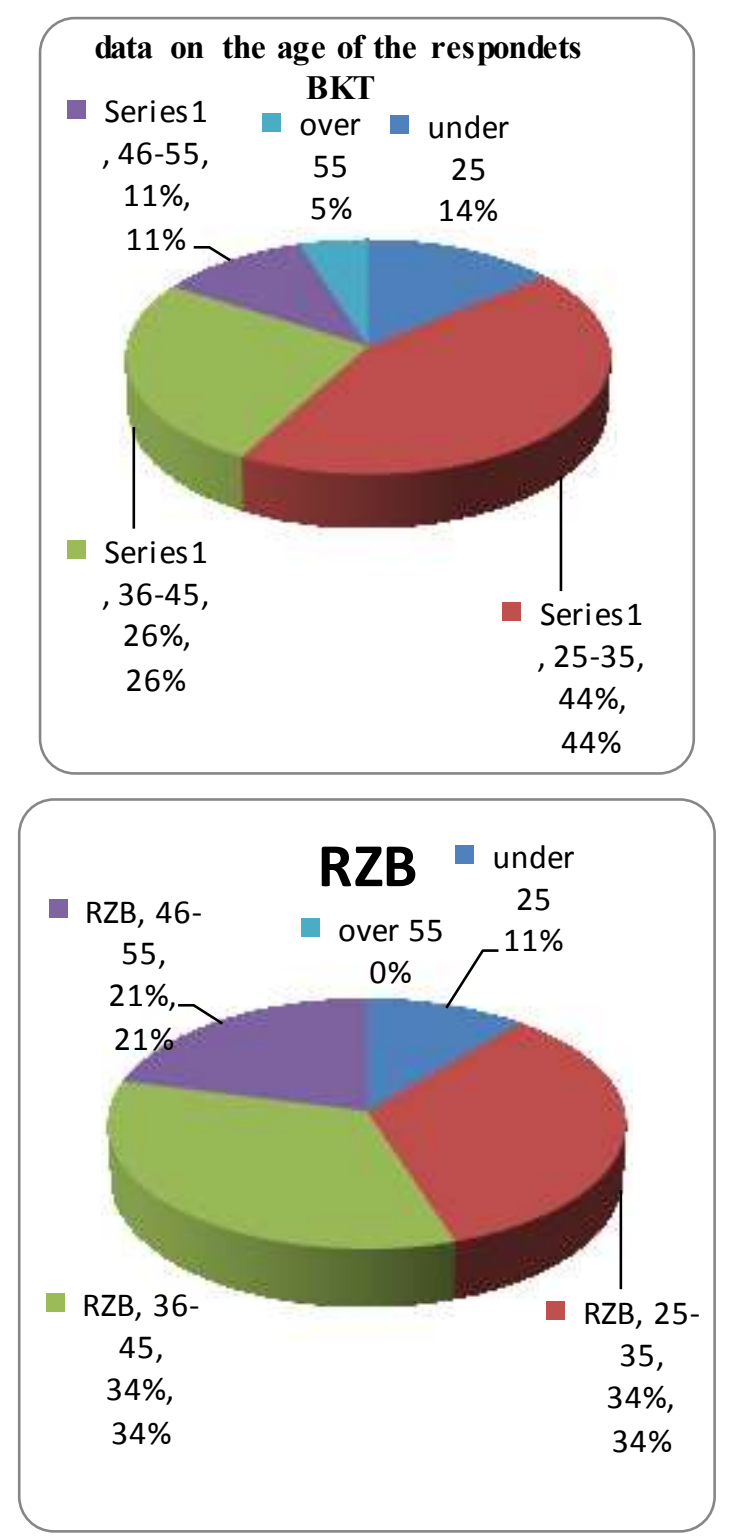

Fig. 3 Data on age

For RZB, $11.7 \%$ of respondents were under 25 years of age and $33.8 \%$ were between 25 and 35 years old, while $20.6 \%$ were between 46 and 55 years old. For NCB $14.5 \%$ of respondents were less than 25 years old and $43.5 \%$ were between 25 and 35 , while $25.8 \%$ between 36 and $45,11.3 \%$ between 46 and 55 years old, and $5 \%$ over 55 years. This shows that the majority of respondents were in the age group of active population (25-45 years old)

\section{Information on education}

All respondents had completed at least high school (63\% of them), 17.8\% of high school (bachelor), and further study $16.9 \%$. 


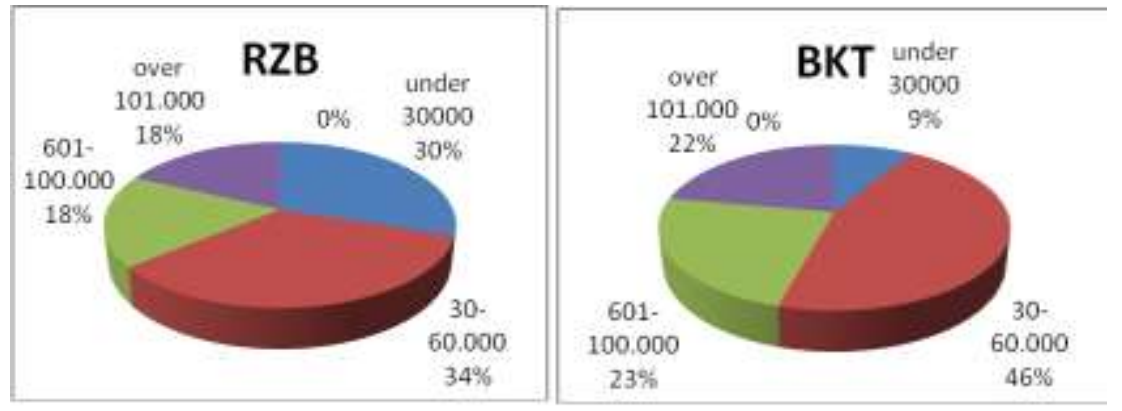

Fig. 4. Data on income level

For RZB, $29.9 \%$ of ALL income under 30,000 per month, 33.8\% between $30.000-60.000,18.2 \%$ 60.000-100.000 and other over then 100,000.

For NCB, $6 \%$ below $30,000,50 \%$ between $30-60000,37 \%$ betwween $60-100000$ and $7 \%$ over than 100,000

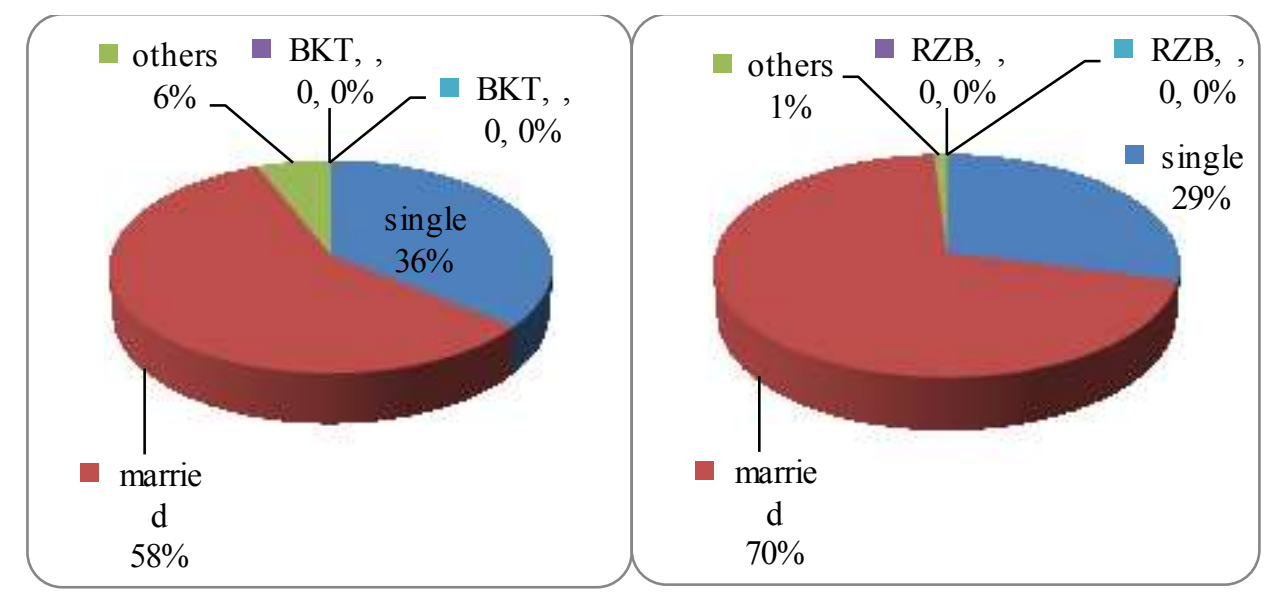

Fig. 5 Data on civil status

A summary of demographic characteristics is given in the table below

Table. 2 A summary of demographic

\begin{tabular}{|c|c|c|c|c|c|}
\hline \multirow{3}{*}{ Variabel } & \multirow{3}{*}{ Category } & \multicolumn{2}{|c|}{ RZB } & \multicolumn{2}{|l|}{ BKT } \\
\hline & & \multicolumn{2}{|c|}{$\mathrm{n}=77$} & \multicolumn{2}{|c|}{$\mathrm{n}=62$} \\
\hline & & Frecuency & Percentage & Frecuency & Percentage \\
\hline \multirow[t]{2}{*}{ Gender } & Female & 40 & 51.9 & 27 & 43.5 \\
\hline & Male & 37 & 48.1 & 35 & 56.5 \\
\hline \multirow[t]{5}{*}{ Age } & Under 25 & 9 & 11.7 & 9 & 14.5 \\
\hline & $25-35$ & 26 & 33.8 & 16 & 25.8 \\
\hline & $36-45$ & 26 & 33.8 & 16 & 25.8 \\
\hline & $46-55$ & 16 & 20.8 & 7 & 11.3 \\
\hline & Over 55 & - & - & 3 & 4.8 \\
\hline
\end{tabular}




\begin{tabular}{|c|c|c|c|c|c|}
\hline \multirow[t]{3}{*}{ Education } & Postgraduate & 13 & 16.9 & 5 & 8.1 \\
\hline & Bachelor & 16 & 17.8 & 5 & 8.1 \\
\hline & Secondary & 48 & 65.3 & 52 & 83.9 \\
\hline \multirow{4}{*}{$\begin{array}{l}\text { Income } \\
\text { ALL }\end{array}$} & Under 30.000 & 23 & 29.9 & 4 & 6.5 \\
\hline & $30-60.000$ & 26 & 33.8 & 23 & 37.1 \\
\hline & $61-100.000$ & 14 & 18.2 & 12 & 19.4 \\
\hline & $100.000+$ & - & - & 11 & 17.7 \\
\hline \multirow[t]{3}{*}{ Civil status } & Married & 54 & 70.1 & 36 & 58.1 \\
\hline & Single & 22 & 28.6 & 22 & 35.4 \\
\hline & Other & 1 & 1.3 & 4 & 6.5 \\
\hline
\end{tabular}

In the table are used the following abbreviations

\begin{tabular}{l}
\hline MW- Much worse from what I expected \\
\hline W- Worse from what I expected \\
\hline EE-Equal to expectation \\
BE-Better from what I expected \\
MB-Much better than what I expected \\
\hline
\end{tabular}

Demographic variables and customer satisfaction

Table.3 Demographic variables and customer satisfaction

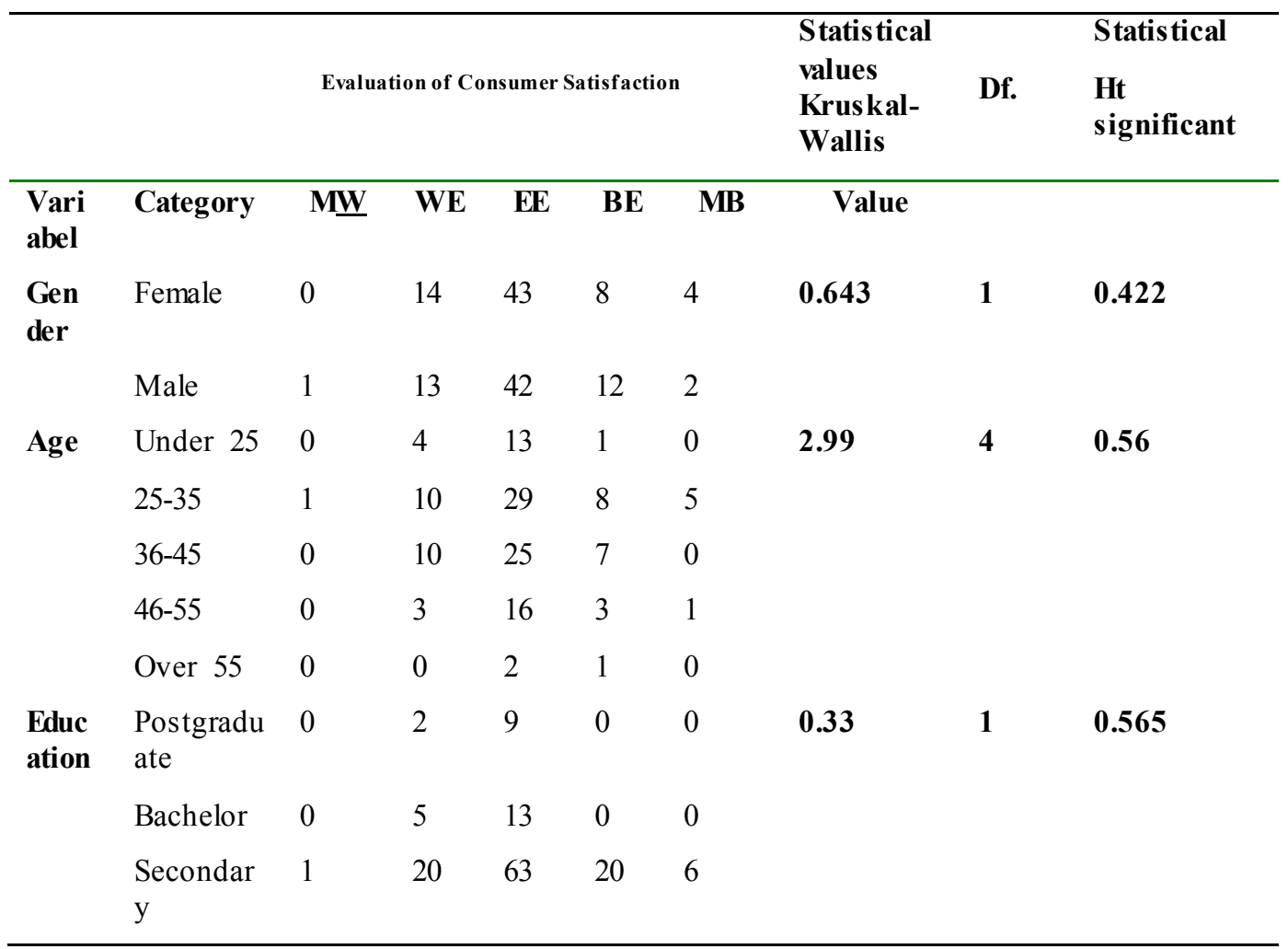




\begin{tabular}{llllllllll}
\hline $\begin{array}{l}\text { Inco } \\
\text { me }\end{array}$ & $\begin{array}{l}\text { under } \\
30.000\end{array}$ & 0 & 2 & 2 & 0 & 0 & $\mathbf{1 1 . 0 3 3}$ & $\mathbf{4}$ & $\mathbf{0 . 0 2 6}$ \\
& $\begin{array}{l}30- \\
60.000\end{array}$ & 1 & 9 & 32 & 4 & 0 & & & \\
& $61-$ & 0 & 6 & 27 & 4 & 1 & & & \\
& 100.000 & & & & & & & & \\
& $100.000+$ & 0 & 10 & 24 & 12 & 5 & & & \\
Civil & Maried & 0 & 15 & 55 & 15 & 5 & $\mathbf{3 . 4 3 7}$ & $\mathbf{2}$ & $\mathbf{0 . 1 7 9}$ \\
status & & & & & & & & & \\
& Single & 1 & 11 & 26 & 5 & 1 & & & \\
& Other & 0 & 1 & 4 & 0 & 0 & & & \\
\hline
\end{tabular}

Results show that, overall differences in consumer satisfaction from the quality of internet banking services vary only between income groups. Thus, consumer satisfaction and services quality have a statistically strong relation only to the categories of income, and does not seem to be strong links to other categories such as age, education or civil status.

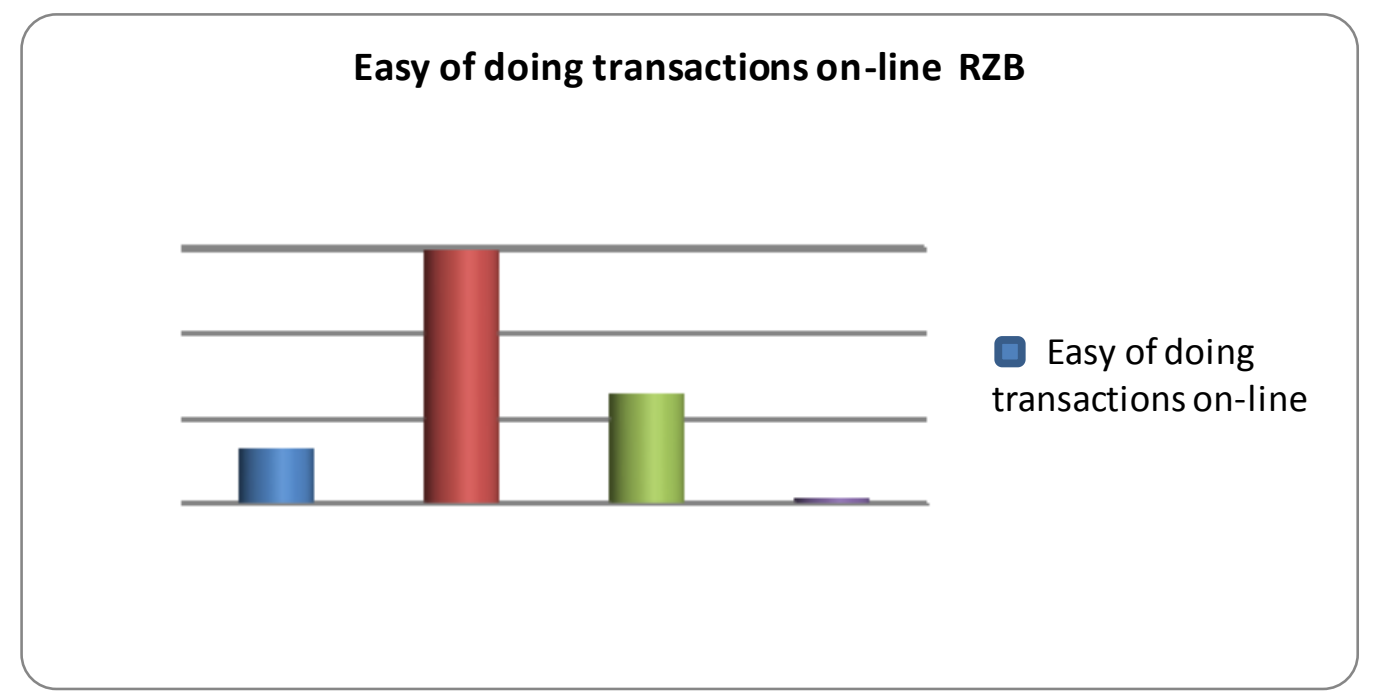

Fig.6 Ease of doing transactions on-line

\begin{tabular}{lcccc}
\hline & W & E & B & MB \\
\hline Ease of doing transactions on-line & $13 \%$ & $59.70 \%$ & $26 \%$ & $1.30 \%$ \\
\hline
\end{tabular}




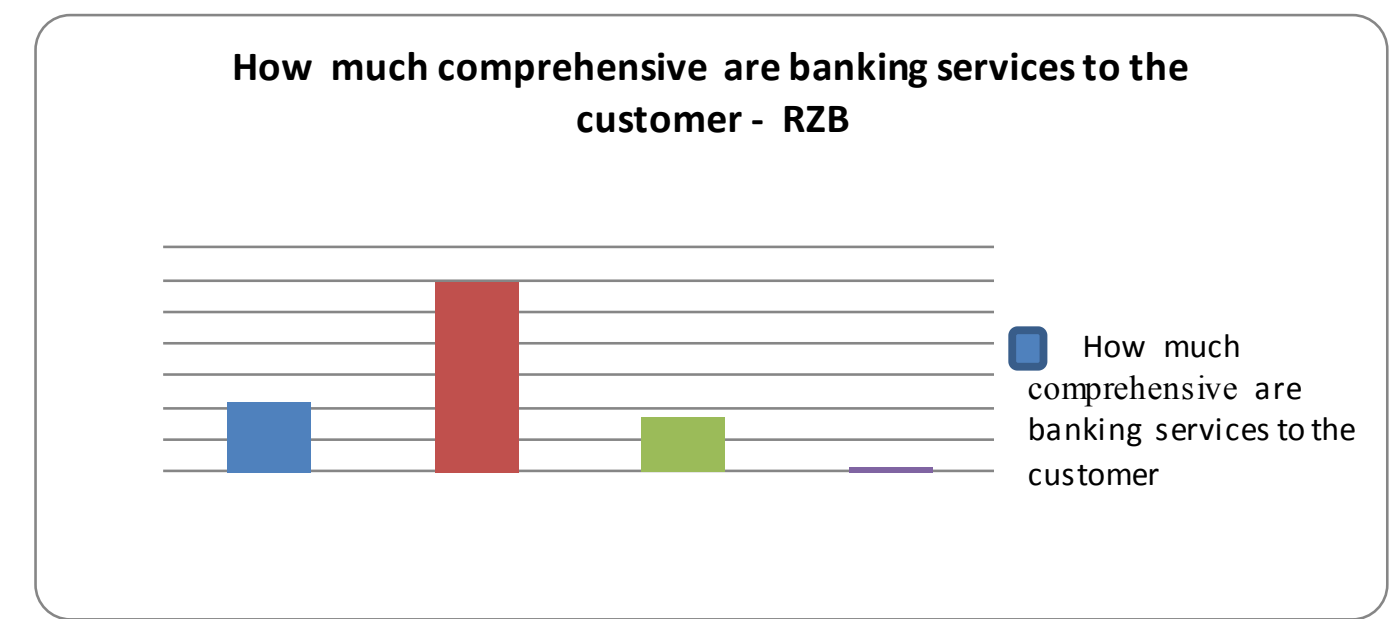

Fig. 7 How much comprehensive are banking services to the customer

\begin{tabular}{lcccc}
\hline & W & E & B & MB \\
\hline $\begin{array}{l}\text { How comprehensive are banking } \\
\text { services RZB }\end{array}$ & $22 \%$ & $59.70 \%$ & $17 \%$ & $1.30 \%$ \\
\hline
\end{tabular}

\section{Accuracy of information}

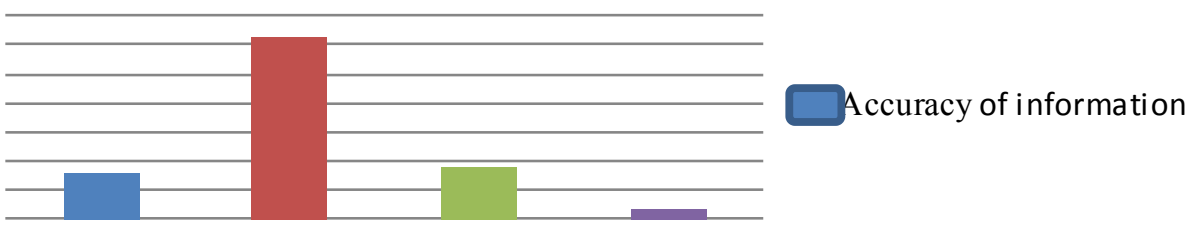

Fig. 8 Accuracy of information received from the bank

\begin{tabular}{ccccc}
\hline & W & E & B & MB \\
\hline Accuracy of information & $16 \%$ & $62.30 \%$ & $18 \%$ & $3.90 \%$
\end{tabular}

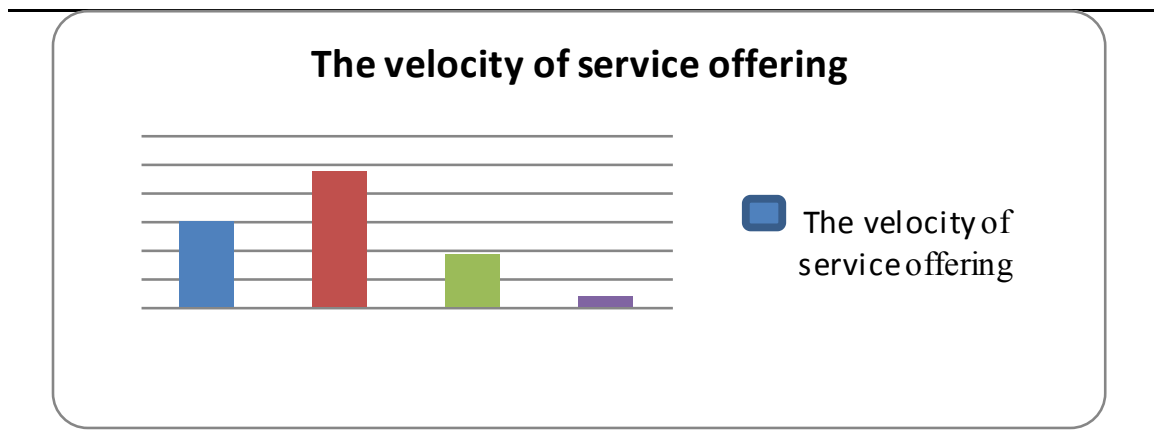

Fig.9 The velocity of service offering 


\begin{tabular}{ccccc}
\hline & MW & WE & EE & BE \\
\hline The velocity of service offering & $30 \%$ & $48.10 \%$ & $18 \%$ & $3.90 \%$ \\
\hline
\end{tabular}

\section{Conclusions and Recommendations}

- The role of service quality in achieving consumer satisfaction is defined as a priority by respondents in the study and practice as emphasized its importance in the literature.

- There are some areas in which literature and the opinion of the managers are seen as very separate. For example, marketing managers give the highest priority to price, which does not occur in literature.

- Another example is the development of new product, which refers quite literature, but from managers considered less priority. The reason that managers give lower priority has nothing to do with the fact that they see it as trivial, but think that improvements in this area is not easily made.

- Services should be perceived as quality of customer banking.

- Quality of service helps to achieve consumer loyalty and confidence building to the bank, just like in any other business. Bankers may perceive quantitative services in terms of number of branches, ATMs, and the number and types of accounts offered. Services may be perceived by customers as quality in terms of attention around their needs. Quick service and competent help ensure consumer satisfaction. The ability to listen is key to building confidence to customers.

\section{Conclusions}

As a result, the percentage of consumers who make online transactions through Internet banking is 9 percent, this means that e-banking is in its early stages of growth in the banking sector, as long as it is a new service and will have the ability to progress and expand in the near future.

This can be explained by several reasons:

- First, the lack of specific infrastructure, where Internet use is mainly used by ages under 40 who are prone to curiosity to new services.

- Secondly, the lack of support Electronic payment systems, a significant proportion of the respondents were not familiar with internet banking terms mentioned in this project. According to some of the customers are not informed about new developments and innovations in the banking sector and they face a lack of information, which depended mainly on the relationship between banks and potential customers.34 percent of respondents have a debit card, while Internet banking is used by only 15 percent of them. The main reason why they do not use Internet Banking service is the loss of security, as a result of incorrect or no knowledge of certain information related to security and banking technology.

- Finally, it is important to note the optimism with which Albanians see the future use of Internet Banking. The new technology changes in the Albanian banking sector are a positive sign, promising a better future, based on the advantages of e-banking and also one of the most important is the fastest way in which customers can perform their transactions on-line.

- Changes in consumer satisfaction between the two banks connected to the Internet banking service noted evidence of a higher level of satisfaction for customers of National Commercial Bank

The differences can be explained by:

- providing preferential rates

- speed Promotion use of portal-largest offering these services by National Commercial Bank 
- It was noted evidence of a strong link between satisfaction of Internet Banking service and service quality between groups with different levels of income and education, but no difference was observed in groups according to gender, age or civilian status.

- In terms of the impact of Internet Banking in total satisfaction were observed evidence of such an impact on both banks of the two banks

- For the main reason for the low usage of Internet banking has low public trust to online transactions and lack of infrastructure. Albania still a good percentage of the population has a bank account.

- Lack of knowledge of technology is another factor that hinders the widespread use of Internet Banking.

- It was noted that this is an argument that does not usually found in the theoretical literat ure but that is typical of developing countries such as Albania.

- The low number of users of Internet Banking is an indication that Albania is still in its initial stages of the development of this banking service

\section{References}

1. Berry, Leonard L, R.Bennet and David W. Carter. Brown, Service Quality: A Profit

2. Booms, BH And Bitner, MJ (1991), \&; Marketing Strategies and Organizations

3. Raiffeisen Bank

4. Publishing the Bank of Albania

5. National Bank publications.

6. .cambrige MA, Marketing Science Institute, May 1983) Report 83-104.

7. Catthy Goodwin , "ICan Do it Myself" : Training the Service Consumer to Contribute to Service Productivity”. Journal of Services Marketing, Vol.2 (Fall 1988) pp 71-78.

8. Christian Gron Roos, Strategic Management and Marketing in the Services Sector

9. Coivell Donald, The Marketing of Services (London: Heinemann, 1984)

10. Czepiel John, Michael R. Solomon and Carol F. Surprenant (Eds), The Services Encounter (Lexington, MA: D.C. Heather / Lexington Books, 1985).

11. Davidoë William H. and Brolltal, Total Customer Service: The ultimate Weapon ( New York: Harper Collins , 1989)

12. Digman, L. Strategic Management

13. G.Morgan,The service Industries Journal, (1998), 14 (2), 153-169.

14. Gerhung J.I and I.D.MILES, The New Service Economy (London: Frances Pinter, 1983)

15. Gronroos Christian, Strategic Management and Marketing in the Service Sector (Helsingborg, Helsinki, Finland: Swedish School of Economics and Business Administration, 1982)

16. Gronroos, Christian, (1980) Designing a Long Range Marketing Strategy for Services: Long Range Planning, April.

17. Gronroos, Christian, (1982 a) A Service Quality Model and its Management Implications, Research Report Work shop into the Management of the services Business, EI ASM London Business School, London.

18. Hall, Eduard T.(1981), Beyond Culture, Anchor Books, USA

19. Hall, Eduard T.(1990) Understanding Cultural Differences 